\title{
Analisis Kebutuhan Informasi Obat Pada Pasien Geriatri Dengan Diabetes Mellitus Di Kota Samarinda
}

\author{
Dewi Rahmawati \\ Laboratorium Penelitian dan Pengembangan Kefarmasian "Farmaka Tropis", \\ Fakultas Farmasi, Universitas Mulawarman, Samarinda, Indonesia \\ Email: dewi@farmasi.unmul.ac.id
}

\begin{abstract}
ABSTRAK
Pada pasien diabetes mellitus sering terjadi polifarmasi hal ini dapat meningkatkan risiko terjadinya efek samping obat, kerentanan deprsi, gangguan kongnitif, risiko hipoglikemia dan risiko terjatuh pada kelompok geriatri. Pada kelompok geriatri penggunan obat harus dipertimbangkan beberapa masalah yang sering timbul diantaranya adalah kemampuan untuk mengurus diri, sering lupa instruksi pengobatan, mengalami tremor dan gangguan visual. Hal ini yang dapat menyulitkan pasien untuk menggunakan obat secara tepat sesuai dengan instruksi tenaga. Penelitian yang dilakukan merupakan penelitian deskritif non experimental dengan pengambilan data pasien geriatri diabetes mellitus secara prospektif di Apotek Instalasi Rawat Jalan RSUD Abdul Wahab Sjahranie, dan Apotek Instalasi Rawat Jalan RS Islam Samarinda. Penelitian ini dibagi dua tahap yaitu tahap kualitatif dan kuantitati. Pada tahap kualitatif dengan melakukan wawancara in depth interview dan tahap kuantitatif dengan menyebarkan kuisioner. Hasil penelitian pada tahap kualitatif menunjukan beberapa kebutuhan pelayanan informasi obat yang dibutuhkan oleh pasien geriatri diabetes diantaranya yaitu: (1) penulisan etiket yang ditulis dengan jelas dan besar; (2) menuliskan kegunaan obat;(3) menyampaikan dengan jelas cara penggunaan obat; (4) membuatkan catatan kecil kapan mengunakan obat dan cara penggunaanya; (5) menyampaikan efek samping obat-obat. Pada Tahap kuantitatif diperoleh data persentase penulisan etiket $68,98 \%$; kegunan obat $57,89 \%$; cara penggunaan obat $55,79 \%$; catatan kecil 45,67\%; efek samping obat 37,65\%. \%. Kebutuhan pelayanan informasi obat pada pasien diabetes mellitus bahwa penulisan etiket yang jelas dan besar merupakan kebutuhan terpenting.
\end{abstract}

Kata Kunci: pelayanan; informasi obat;penggunaan obat; in depth interview

DOI: https://doi.org/10.25026/mpc.v7i1.286

\section{PENDAHULUAN}

Dua puluh tahun belakangan ini peningkatan diabetes mellitus pada lansia atau geriatri sangat tinggi dibandingkan kelompok usia lainnya. Di Indonesia terjadinya peningkatan prevalensi penyakit diabtes mellitus pada pasien dengan umur 65 sampai 75 tahun sebesar $18 \%$, sedangkan umur dibawah 45 tahun hanya sebesar 1,2\%. Hal ini sesuai dengan prediksi American Diabetes Association, bahwa diabetes mellitus pada orang yang berusia 65 tahun keatas akan meningkat sekitar $56 \%$ antara tahun 
2002 sampai 2020. ${ }^{1,2}$ Penurunan toleransi glukosa pada kelompok geriatric ini berkaitan dengan berkurangnya sensitivitas sel perifer terhadap efek insulin (resistensi insulin) sehingga mengurangi kemampuan tubuh dalam memetabolisme glukosa. Produksi insulin pada beta pankreas juga akan mengalami penurunan dan perlambatan. Pada pasien geriatri, kombinasi dari hal-hal tersebut dapat meningkatkan konsentrasi glukosa darah dan lebih memperburuk terjadinya hiperglikemia.

Pada pasien diabetes mellitus ini polifarmasi mungkin tidak dapat dihindarkan karena penggunaan obat digunakan untuk mengontrol kadar gula darah maupun untuk mengatasi gangguan lainnya. Polifarmasi ini dapat meningkatkan risiko terjadinya efek samping obat, kerentanan depresi, gangguan kongnitif, dan risiko hipoglikemia pada kelompok geriatri. ${ }^{4}$ Pada kelompok geriatri penggunan obat harus dipertimbangkan beberapa masalah yang sering timbul diantaranya adalah kemampuan untuk mengurus diri, sering lupa instruksi pengobatan, mengalami tremor dan gangguan visual. Hal ini yang dapat menyulitkan pasien untuk menggunakan obat secara tepat sesuai dengan instruksi tenaga kesehatan. ${ }^{5}$

Berdasarkan hal tersebut di atas, maka perlu dilakukan penelitian untuk melihat seberapa besar kebutuhan dan apa saja pelayanan informasi obat yang dibutuhkan oleh pasien geriatric diabetes mellitus di kota Samarinda.

\section{METODE}

Penelitian yang dilakukan merupakan penelitian deskritif non experimental, metode penelitian yang digunakan adalah kualitatif dan kuantitatif. Pada tahap secara kualitatif yang bertujuan untuk memperoleh gambaran bagaimana apa saja kebutuhan pelayanan informasi obat yang dibutuhkan oleh pasien geriatri diabetes dengan wawancara in depth interview di
Instalasi Rawat Jalan RSUD Abdul Wahab Sjahranie, Instalasi Rawat Jalan RS Islam Samarinda. Pada tahap kuantitatif untuk persentase kebutuhan pelayanan informasi obat yang dibutuhkan oleh pasien geriatri diabetes mellitus dengan menggunakan kuisioner daftar pertanyaan kebutuhan pelayanan informasi pasien geriatri diabetes mellitus di Instalasi Rawat Jalan RSUD Abdul Wahab Sjahranie Samarinda.

Populasi target penelitian adalah seluruh pasien geriatri diabetes mellitus di Instalasi Rawat Jalan RSUD Abdul Wahab Sjahranie Populasi terjangkau adalah pasien diabetes mellitus yang berada di Instalasi Rawat Jalan RSUD Abdul Wahab Sjahranie pada periode penelitian. Pada tahap pertama, pengambilan sampel dilakukan dengan teknik nonprobability sampling secara purposive sampling.

1. Kriteria inklusi dalam penelitian ini adalah sebagai berikut.

- Pasien geriatri baik laki-laki dan perempuan berusia antara $\geq 60$ tahun.

- Pasien yang terdiagnosa oleh dokter menderita diabetus mellitus (DM) dengan atau tanpa komplikasi.

- Pasien yang mendapatkan obat antidiabetes (OAD) maupun insulin.

- Pasien yang tidak buta huruf.

- Pasien yang bersedia mengikuti penelitian dengan menandatangani informed concern.

2. Kriteria eksklusi dalam penelitian ini adalah sebagai berikut.

- $\quad$ Pasien yang tuli

\section{HASIL DAN PEMBAHASAN}

Penelitian ini dibagi menjadi dua tahap yaitu kualitatif dan kuantitatif, penelitian ini dilaksanakan selama bulan Juni 2016 -Januari 2017 dilakukan di Rumah Sakit kota Samarinda yaitu RSUD A.W Sjahranie dan RS Islam Samarinda. Penelitian yang dilakukan 
merupakan penelitian deskritif non experimental dengan pengambilan data pasien secara prospektif pada pasien geriatri diabetes mellitus di RS kota Samarinda. Pada tahap kualitatif subyek dalam penelitian ini sebanyak 41 orang pasien diperoleh hasil rekaman wawancara in depth interview dipindahkan dalam bentuk transkip untuk kemudian dilakukan pengkodean dan pengkategorian. Dari hasil pengkategorian, diperoleh temuan mengenai kebutuhan pelayanan informasi obat yang dibutuhkan oleh pasien geriatri diabetes dapat dikelompokkan menjadi:
(1) penulisan etiket yang ditulis dengan jelas dan besar; (2) menuliskan kegunaan obat;(3) menyampaikan dengan jelas cara penggunaan obat; (4) membuatkan catatan kecil kapan mengunakan obat dan cara penggunaanya; (5) menyampaikan efek samping obat-obat.

Pada tahap penelitian kuantitatif, dilaksanakan selama bulan Okotober 2016 - Januari 2017. Subyek penelitian sebanyak 150 pasien diperoleh data karakteristik pasien berupa data: usia, jenis kelamin, tingkat pendidikan, dan jenis pekerjaan.

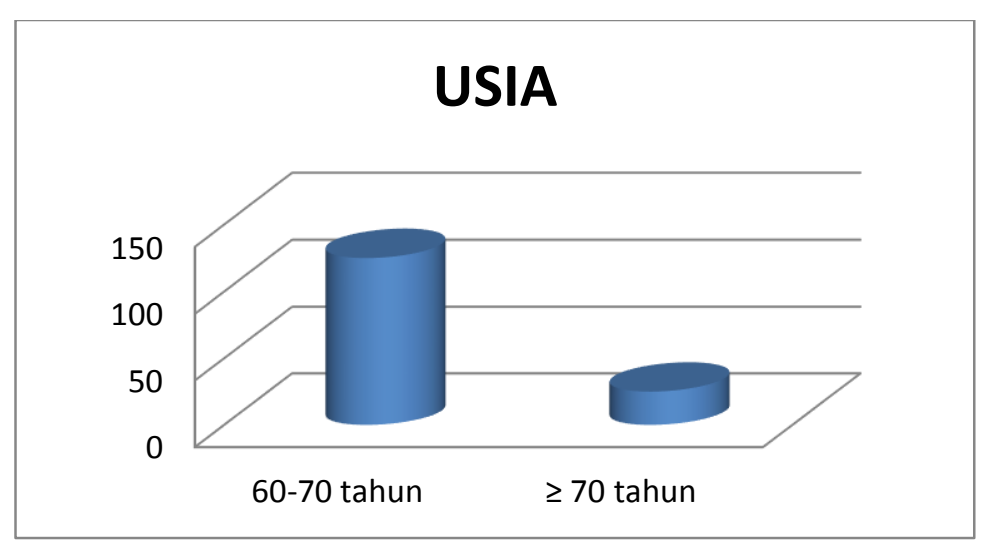

Gambar 1 Usia Pasien Geriatri Diabetes Mellitus di Kota Samarinda

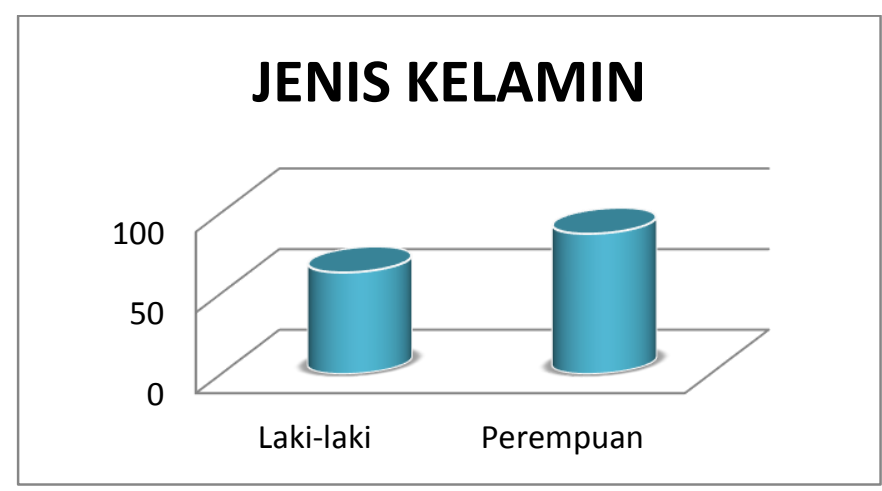

Gambar 2. Jenis Kelamin Pasien Geriatri Diabetes Mellitus di Kota Samarinda 


\section{PENDIDIKAN TERAKHIR}

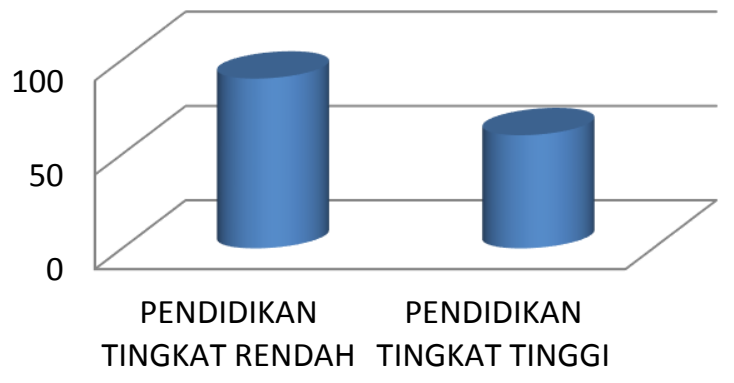

\section{Grafik Tingkat Pendidikan Pasien Geriatri Diabetes Mellitus di Kota Samarinda}

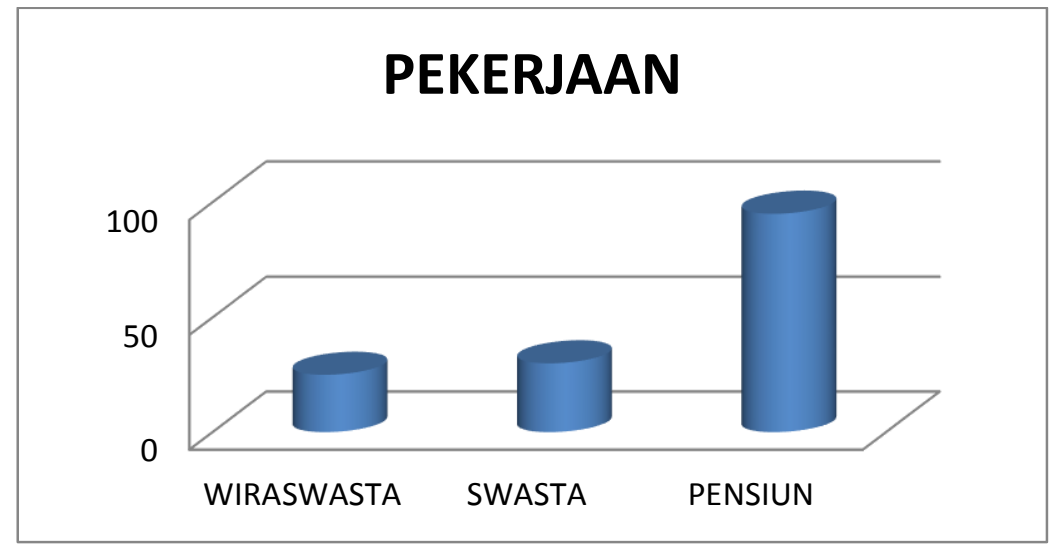

Grafik Pekerjaan Pasien Geriatri Diabetes Mellitus di Kota Samarinda

Dari data yang diperoleh pada Gambar 1, dapat dilihat bahwa usia geriatri rata-rata pasien geriatri diabetes mellitus adalah usia dewasa yaitu 60-70 tahun. Dari hasil data karakteristik usia ini mengambarkan bahwa usia harapan hidup pada geriatri paling banyak pada usia tersebut. Pada usia 55- 65 tahun ini merupakan kelompok umur yang mencapai tahap pranisium, pada tahap ini akan mengalami keterbatasan yaitu pasien pikun/ sering lupa instruksi pengobatan, mengalami tremorm gangguan visual. Karena semakin tinggi usia pasien maka fungsi organ tubuh sangat berpengaru, penurunan daya tahan tubuh dan berbagai tekanan psikologis. Hal ini sangat berkait dengan kebutuhan pasien terhadap pelayanan informasi obat.
Dari data yang diperoleh pada Gambar 2, dapat dilihat bahwa jenis kelamin terbanyak pasien geriatri diabetes mellitus di kota samarinda adalah perempuan. Pada penelitian ini menunjukan bahwa usia geriatri pada perempuan lebih banyak yang masih memiliki harapan hidup dikarenakan faktor merawat diri dan peduli terhadap diri dan penyakit yang diderita lebih besar daripada laki-laki.

Dari data pada Gambar 3, dapat diperoleh pendidikan terakhir konsumen apotek terbanyak adalah pendidikan tingkat tinggi. Pendidikan tingkat tinggi yaitu SMA dan perguruan tinggi baik strata 1 (S1), strata 2 (S2) maupun strata 3 (S3). Penelitian ini menujukan bahwa pendidikan tinggi sangat berpengaruh pada pengetahuan, sosial ekonomi dan 
kemandirian yang makin mantap. Data karakteristik ini di ambil pada peneliian ini untuk dapat mengambarkan hasil dari kebutuhan pelayanan informasi obat terkait dengan pengetahuan pasien mengenai obat-obat dan pemahaman pasien terkait pengobatannya.

Dari data pada Gambar 4, dapat diperoleh pekerjaan pasien geriatri diabetes mellitus terbanyak adalah pensiun. Pada usia terbanyak adalah umur 60-70 tahun dimana pada tahap usia ini umumnya sudah memiliki keterbatasan dalam pikiran dan aktivitas. Sehingga pada pasien pekerja swasta maupun pewagai negeri sipil pada usia ini merupakan waktu mereka untuk pensiun. Data karakteristik ini di ambil berkaitan erat dengan kebutuhan pasien terkait pelayanan informasi obat.

Hasil dari temuan tahap kualitatif tersebut akan di lakukan analisis dengan melihat persentase kebutuhan pelayanan informasi obat yang dibutuhkan oleh pasien geriatri diabetes mellitus. Hasil dapat dilihat pada Tabel 1.

Tabel 1. Analisis Data Kebutuhan Pelayanan Informasi Obat pada Pasien Geriatri Diabetes Mellitus Di Kota Samarinda

\begin{tabular}{|l|l|l|l|}
\hline Pelayanan informasi obat pasien geriatri & $\begin{array}{l}\text { Sangat } \\
\text { penting }\end{array}$ & Penting & $\begin{array}{l}\text { Kurang } \\
\text { penting }\end{array}$ \\
\hline Penulisan etiket & $68,98 \%$ & $25,82 \%$ & $5,2 \%$ \\
\hline Kegunaan obat & $57,89 \%$ & $23,55 \%$ & $18,56 \%$ \\
\hline Cara penggunaan obat & $55,79 \%$ & $20,56 \%$ & $23,65 \%$ \\
\hline Catatan kecil (penggunaan \& kegunaan obat) & 45,67 & $25,67 \%$ & $28,66 \%$ \\
\hline Efek samping obat & $37,65 \%$ & $26,7 \%$ & $35,65 \%$ \\
\hline
\end{tabular}

Dari data tabel 1, kebutuhan pelayanan informasi obat yang dibutuhkan oleh pasien geriatri diabetes mellitus menunjukan bahwa penulisan etiket yang jelas dan besar sangat penting diperoleh data sebesar 68,98\%, selanjutnya kegunaan obat dan cara penggunaan obat juga mendapat nilai diatas $50 \%$ sebesar $57,89 \%$ dan $55,79 \%$. Hal ini menunjukan bahwa pada pasien geriatri memiliki penurunan fungsi organ sebesar\%. Pada penelitian ini pasien merupakan pasien geriatri dan menderita penyakit diabetes mellitus, kondisi ini pasien akan mudah sekali terjadi hiperglikemia. Hal ini disebabkan oleh karena fungsi organ menurun terutama pankreas yang berfungsi menghasilkan hormon insulin. Jika terjadi kondisi hiperglikemia akan mempengaruhi terjadinya komplikasi mikrovaskular maupun makrovaskular. Sehingga pada pasien ini akan menyebabkan keterbatasan dalam mengingat sesuatu /pikun dan gangguan visual yang merupakan salah satu komplikasi mikrovaskular.

\section{KESIMPULAN DAN SARAN}

Pada penelitian ini diperoleh Kebutuhan pelayanan informasi obat pada pasien diabetes mellitus bahwa penulisan etiket yang jelas dan besar merupakan kebutuhan terpenting. Saran dapat dilakukan penelitian lanjutan dengan intervensi menggunakan temuan kebutuhan pelayanan informasi pada pasien geriatric diabetes mellitus menggunakan rancangan penelitian before after study maupun $R C T$ dengan subyek penelitian pasien geriatric diabetes mellitus. 
DAFTAR PUSTAKA

[1] American Diabetes Association. 201. Definition and Classification of Diabetes Mellitus. Diabetes Care.

[2] Ham RJ, dkk. 2007. Primary Care Geriatrics A Case-Based Approach Fifth Edition. Elsevier Mosby. USA. Hlm 485-492.

[3] Springhouse. 1999. Handbook of Geriatric Nursing Care. Lippincott Williams \& Wilkins. USA. Hlm 215.

[4] Kurniawan I. 2010. Diabetes Mellitus Tipe 2 Pada Usia Lanjut. Dalam: Majalah Kedokteran Indonesia. IDI. Jakarta. Hlm 595696.

[5] Martono. H., Pranaka K. 2014. Geriatri (Ilmu Kesehatan Usia Lanjut) Edisi ke-5. Badan Penerbit FKUI. Jakarta

[6] PERKENI. 2006. Konsensus Pengelolaan dan Pencegahan Diabetes Mellitus Tipe 2 di Indonesia. Pengurus Besar Perkumpulan Endokrinologi Indonesia : Jakarta.
[7] John MF. 2007. Diabetes Mellitus Klasifikasi, Diagnosis, Cara Skrining dan Alogaritme Penatalaksanaan Diabetes Mellitus Tipe 2. Dalam: Endkrinologi Klinik. Editor: Sri Hartini, dikk. PII Bagian Ilmu Penyakit Dalam Fakultas Kedokteran Unpad : Bandung.

[8] Menteri Kesehatan Republik Indonesia: Standar Pelayanan Kefarmasian di Apotek> Lampiran Keputusan Menteri Kesehatan Nomor 1027/Menkes/SK/XI/2004.

[9] Caspersen CJ, Powell KE, Christenson GM. Physical activity, Exercise and Physical fitness: Definition and districtions for Health-Related Research. Public Health Research. 1985 March-April; 100 (2) : 126-9.

[10]Cipolle RJ, Strand LM, Morley PC. Pharmaceutical Care Practice. New York: McGraw-Hill; 1998.

[11] 